\title{
CONJUNTO PENAL DE TEIXEIRA DE FREITAS: PROSPECÇÃO E ANÁLISE DE DADOS QUANTITATIVOS E QUALITATIVOS
}

\author{
AUTOR: ANDRE CARVALHO MONTEIRO NUNES \\ CO-AUTOR/ORIENTADOR: DAVID SANTOS FONSECA
}

\begin{abstract}
Resumo: Com a intensão de pesquisar a população prisional nacional e regional, esta pesquisa pretende investigar o contexto prisional da região sul do estado da Bahia, com uma demarcação de campo de investigação referente à mesorregião do Sul baiano, dividida em três territórios de identidade, sendo eles: microrregião de Ilhéus-Itabuna, microrregião de Porto Seguro e a microrregião de Valença. A partir da identificação do território, a pesquisa atua na análise das unidades prisionais presentes no sul da Bahia, buscando entender sua organização e funcionamento. $O$ Estudo se desenvolve a partir do levantamento de dados sobre encarceramento no Brasil e as produções acerca do aprisionamento como forma de controle social. A pesquisa de campo também foi feita a partir de visitas às unidades prisionais de Teixeira de Freitas e Eunápolis, que objetivavam agrupar informações sobre o cotidiano desses espaços. O método etnográfico foi o condutor dessa parte do estudo. Diante disso, foi feito um relato de experiências sobre o contexto das unidades prisionais do sul da Bahia de forma que possibilitasse a percepção sobre o espaço que se investiga. A pesquisa avançou no sentido de mapear as unidades prisionais das regiões citadas, além de ter possibilitado aferir in loco as condições em que se encontram quem cumpre pena no sul da Bahia.
\end{abstract}

Palavras-chave: Punitividade, controle social, sistema carcerário. 